\title{
Are the Rhizomyinae and the Spalacinae closely related? Contradistinctive conclusions between genetics and palaeontology
}

\author{
Hans de Bruijn ${ }^{1}$ • Anneke A. Bosma ${ }^{1} \cdot$ Wilma Wessels ${ }^{1}$
}

Received: 18 November 2014 / Revised: 12 February 2015 / Accepted: 15 April 2015 /Published online: 5 July 2015

(C) Senckenberg Gesellschaft für Naturforschung and Springer-Verlag Berlin Heidelberg 2015. This article is published with open access at Springerlink.com

\begin{abstract}
The reconstruction of the evolutionary history of the Rhizomyinae and the Spalacinae based on the fossil record strongly suggests that these do not share the same murid ancestor and developed separately since the early Oligocene. This conclusion is supported by the difference in evolutionary dynamics between these groups during the Miocene and Pliocene. Molecular genetic studies of extant representatives of the Rhizomyinae, Spalacinae and Myospalacinae, however, suggest that these subfamilies share similarities that distinguish them from all other Muridae. As a result, geneticists unite these subfamilies into the family Spalacidae and consider the Spalacidae and the Muridae to be sister lineages. Until the conflict between the two disciplines is resolved we prefer to maintain the Rhizomyinae and the Spalacinae as two subfamilies within the family Muridae (superfamily Muroidea).
\end{abstract}

Keywords Oligocene $\cdot$ Miocene $\cdot$ Rodentia $\cdot$ Spalacinae $\cdot$ Rhizomyinae · Phylogeny

\section{Introduction}

The aim of this review is to compare the results presented by palaeontologists and geneticists who investigated the phylogenetic relationship of the Rhizomyinae and the Spalacinae. In

This article is a contribution to the special issue "Old worlds, new ideas. A tribute to Albert van der Meulen".

Wilma Wessels

w.wessels@uu.nl

1 Department of Earth Sciences, Utrecht University, Heidelberglaan 2, 3584 CS Utrecht, The Netherlands spite of the progress made in both disciplines during the last decade, conclusions remain conflicting.

In the classification of extant mammals by Wilson and Reeder (2005), the fossorial rodents Myospalacinae, Rhizomyinae (including the Tachyoryctinae) and Spalacinae are united into the family Spalacidae, separate from all other Muridae, thus returning to the classical arrangement of Thomas (1896). This view is supported by recent genetic studies which unanimously suggest that the Rhizomyinae and Spalacinae represent the same early branch of the Muridae (in the Muroidea).

The fossil record, however, suggests that the muroid ancestor of each of these subfamilies was different and that their ancestors adapted to a fossorial mode of life during a different period and in a different geographical area. Most palaeontologists therefore interpret the adaptations to a fossorial mode of life shared by these subfamilies to have developed independently (e.g. Flynn et al. 1984; Sen and Sarica 2011). The classification of McKenna and Bell (1997), which includes fossil genera, follows this view and considers the Myospalacinae, Rhizomyinae and Spalacinae to be separate subfamilies of the family Muridae. Other subfamilies of the Muridae containing fossorial species are the extant Arvicolinae and Sigmodontinae and the extinct Anomalomyinae and Tachyoryctoidinae (McKenna and Bell 1997).

The geographic distribution of the extant Myospalacinae, Rhizomyinae and Spalacinae shows that each of the three subfamilies occupies its own geographical area, the Myospalacinae in eastern Asia (mainly China and Mongolia), the Rhizomyinae in south and southeastern Asia (Rhizomys and Cannomys) and in the eastern part of Africa (Tachyoryctes) and the Spalacinae in southeastern Europe and Anatolia (Figs. 1 and 2).

Here, we restrict the discussion to the Rhizomyinae and Spalacinae because these two subfamilies are represented by 


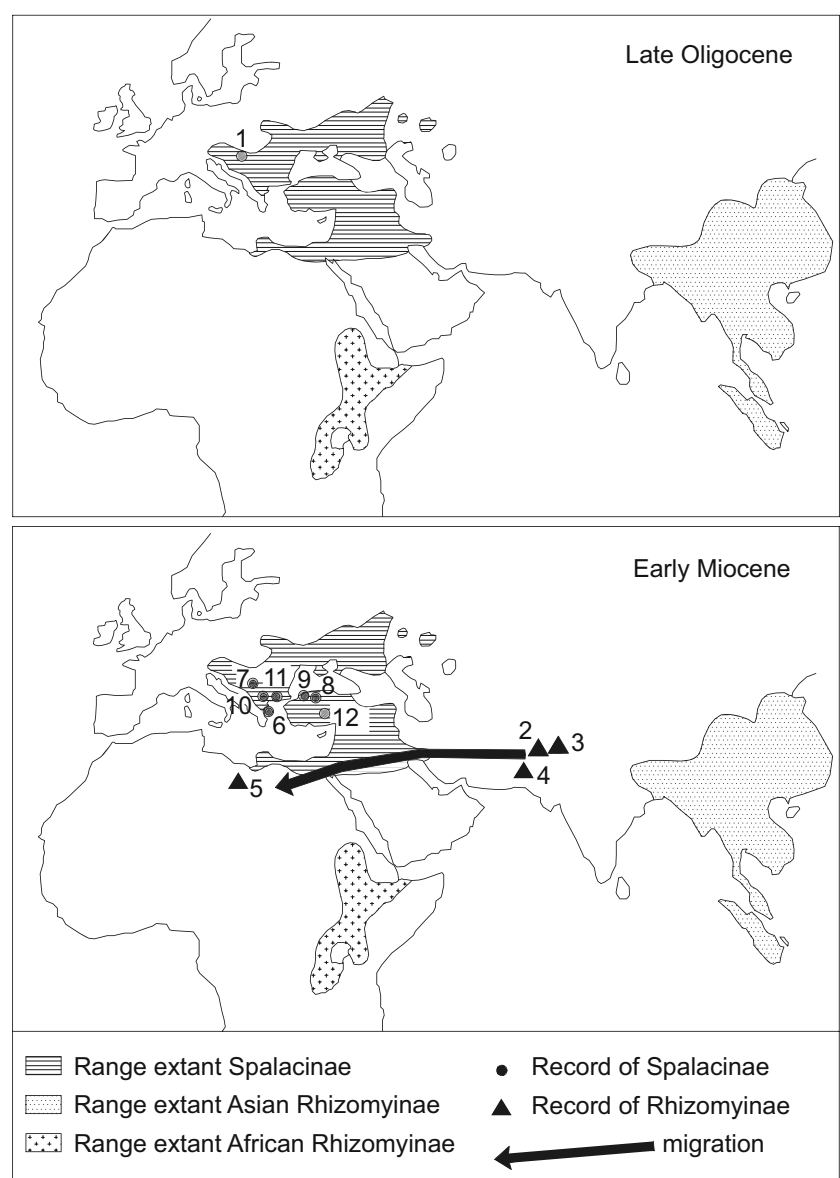

Fig. 1 Sketch maps of present day Eurasia and North Africa showing the major occurrences of the genera and species of the Rhizomyinae and Spalacinae during the late Oligocene and early Miocene. 1 Vetusspalax progressus, Banovići, Bosnia and Herzegovina (De Bruijn et al. 2013), 2 Prokanisamys kowalskii, Zinda Pir Dome, Pakistan (Lindsay 1996), 3 Prokanisamys arifi, Banda daud Shah, Pakistan (De Bruijn et al. 1981), 4 Prokanisamys arifi and P. major, Gaj River, Pakistan (Wessels and De Bruijn 2001), 5 Prokanisamys sp., Jebel Zelten, Libya (Wessels et al. 2003), 6 Heramys eviensis, Aliveri, Greece (Klein Hofmeijer and De Bruijn 1985), 7 Heramys sp., Sibnica, Serbia (Marković 2003), 8 Debruijnia arpati, Keseköy, northeast Anatolia (Ünay 1996), 9 Debruijnia sp., Söke, Dededag, western Anatolia (Sen and Sarica 2011), 10 Pliospalax sp., Karydia, northeastern Greece (Theocharopoulos 2000); 11 Pliospalax sp., Antonios, northeastern Greece (Vasileiadou and Koufos 2005), 12 Pliospalax sp., Çatalarkaç, central Anatolia (not published)

many living species, and both have an exceptionally good fossil record. An overview of the genera and species included in each of these subfamilies is given in Table 1. Author names are provided for in this table, but are omitted in the text. The taxonomic levels applied are family, subfamily, genus and species, following McKenna and Bell (1997) for the Muridae. We neither use tribe, subgenus nor subspecies. Therefore, the Rhizomyinae, as used here, includes the Asian as well as the African genera. Furthermore, we include Sinapospalax into Pliospalax because the differences in dental pattern of the cheek teeth of the species in these genera are very subtle (Figs. 3, 4, 5

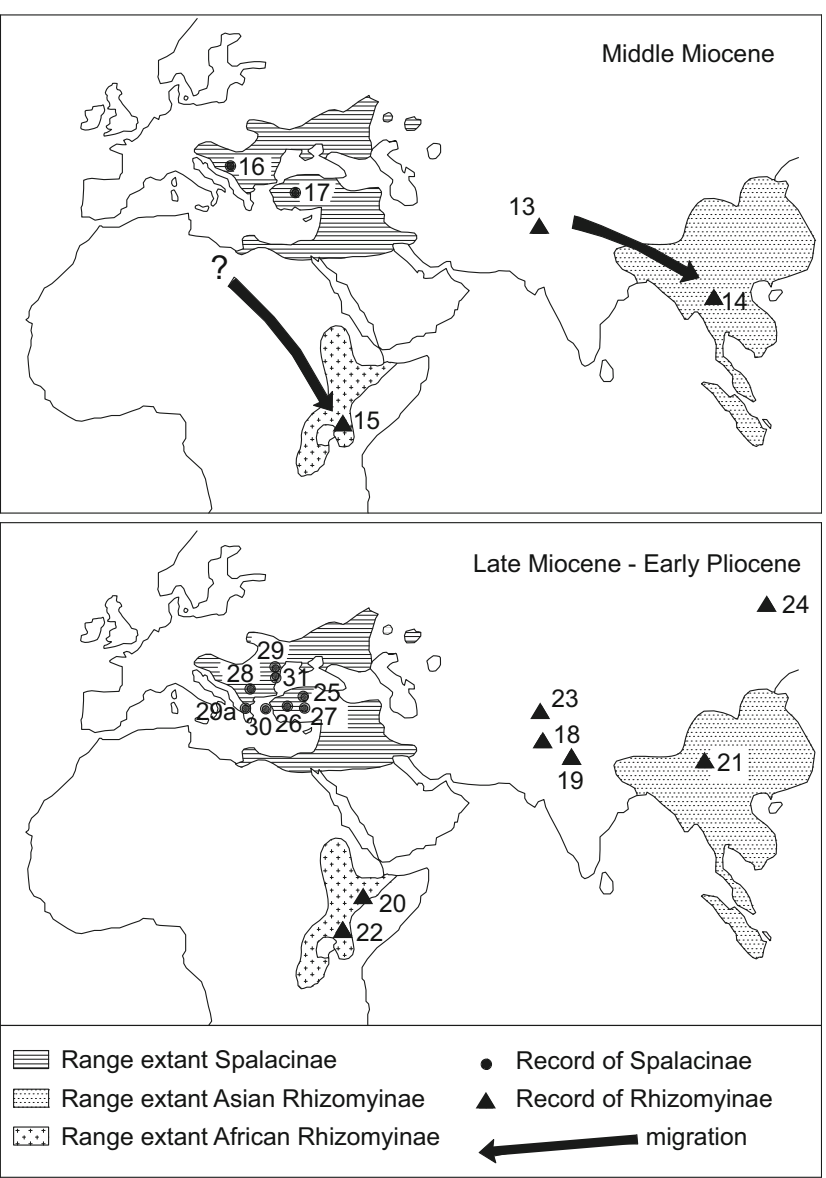

Fig. 2 Sketch maps of present day Eurasia and northern Africa showing the major occurrences of the genera and species of the Rhizomyinae and Spalacinae during the middle Miocene and late Miocene-early Pliocene. 13 Kanisamys indicus and K. potwarensis, Potwar plateau, Pakistan (Wood 1937; Flynn 1982), 14 Prokanisamys benjavuni, Li Basin, Thailand (Mein and Ginsburg 1985), 15 Pronakalimys andrewsi, Fort Ternan, Kenya (Tong and Jaeger 1992), 16 Pliospalax sp., Vracevići, Serbia (Marković 2003), 17 Pliospalax, div. species, diverse localities, Anatolia (Ünay et al. 2003, Sen and Sarica 2011), 18 Eicooryctes, Kanisamys, Miorhizomys, Protachyoryctes, Rhizomyides, Potwar Plateau, Pakistan (Flynn 1982; López-Antoňanzas et al. 2012), 19 Kanisamys, Miorhizomys, Protachyoryctes, Rhizomyides, Haritalyangar and Bilaspur, India (Flynn 1982), 20 Tachyoryctes makooka, Digiba Dora, Ethiopia (Wesselman et al. 2009), 21 Miorhizomys nagrii, M. tetrachorax, Lufeng, China (Flynn and Qi 1982; Flynn 2009), 22 Nakalimys lavocati, Nakali, Kenya (Flynn and Sabatier 1984), 23 Rhizomyides carbonelli, Pul-e Charki, Afghanistan (Brandy 1979), Rhizomyides mirzadi, Bamian Basin, Afghanistan (Lang and Lavocat 1968), 24 Brachyrhizomys shajius, Yushe Basin, China (Flynn 1993), Brachyrhizomys shansius, Yushe Basin, China (Teilhard de Chardin 1942), 25 Heramys anatolicus, Sinap, Anatolia; Pliospalax incliniformis, Sinap, Anatolia, Pliospalax sinapensis, Sinap, Anatolia (Sarica and Sen 2003), 26 Pliospalax complicatus, Amasya, Anatolia (Sen and Sarica 2011), 27 Pliospalax, div sp., div. localities Anatolia (Ünay 1996; Sen and Sarica 2011), 28 Pliospalax macovei, Beresti, Malusteni, Romania (Kormos 1932), 29 Spalax odessanus, Odessa, Ukraine (Topachevski 1969), 29 a Spalax odessanus, Kara Burun, Greece (De Bruijn 1984), 30 Pliospalax sotirisi, Rhodes, Greece (De Bruijn et al. 1970), 31 Pliospalax compositodontus, Andriivka, Ukraine (Topachevski 1969)

and 6). Eumyarion kowalskii, a species which plays an important role in our discussion, has been transferred by 
Table 1 The genera and species of the Rhizomyinae and Spalacinae

\begin{tabular}{|c|c|c|c|}
\hline Subfamily and genus & Species & Occurences & Distribution \\
\hline \multicolumn{4}{|l|}{ Spalacinae Gray, 1821} \\
\hline \multicolumn{4}{|c|}{$\begin{array}{l}\text { Spalax Güldenstaedt, } 1770 \\
\text { (including Nannospalax } \\
\text { Palmer, 1903) }\end{array}$} \\
\hline & ${ }^{\mathrm{a}}$ Spalax microphthalmus Güldenstaedt, 1770 & extant & Russia, Ukraine \\
\hline & At least 16 extant species & extant & $\begin{array}{l}\text { Balkan, Caucasus, } \\
\text { Turkey, coastal area } \\
\text { SE Mediterranean }\end{array}$ \\
\hline & Spalax odessanus Topachevski, 1969 & Early Pliocene & Ukraine, Anatolia \\
\hline \multicolumn{4}{|c|}{$\begin{array}{l}\text { Pliospalax Kormos, } 1932 \\
\quad \text { (Including Sinapospalax } \\
\text { Sarica and Sen, 2003) }\end{array}$} \\
\hline & ${ }^{\text {a }}$ Pliospalax macovei (Simionescu, 1930) & Pliocene & Rumania, Anatolia \\
\hline & Pliospalax compositodontus Topachevski, 1969 & Early Pliocene & Ukraine \\
\hline & Pliospalax sotirisi De Bruijn et al. 1970 & Late Miocene / Early Pliocene & Greece \\
\hline & $\begin{array}{l}\text { Pliospalax tourkobouniensis De Bruijn and } \\
\text { Van der Meulen, } 1975\end{array}$ & Early Pliocene & Greece \\
\hline & Pliospalax canakkalensis Ünay, 1978 & Middle Miocene & Anatolia \\
\hline & Pliospalax primitivus Ünay, 1978 & Middle Miocene & Anatolia \\
\hline & Pliospalax marmarensis Ünay, 1990 & Middle Miocene & Anatolia \\
\hline & Pliospalax incliniformis (Sarıca and Sen, 2003) & Late Miocene & Anatolia \\
\hline & Pliospalax sinapensis (Sarıca and Sen, 2003) & Late Miocene & Anatolia \\
\hline & Pliospalax berdikensis (Sen and Sarıca, 2011) & Middle Miocene & Anatolia \\
\hline & Pliospalax complicatus Sen and Sarıca, 2011 & Late Miocene / Early Pliocene & Anatolia \\
\hline \multicolumn{4}{|c|}{$\begin{array}{l}\text { Heramys Klein Hofmeijer } \\
\text { and De Bruijn, } 1985\end{array}$} \\
\hline & $\begin{array}{l}\text { a Heramys eviensis Klein Hofmeijer and De } \\
\text { Bruijn, } 1985\end{array}$ & Early Miocene & Greece \\
\hline & Heramys anatolicus Sarica and Sen, 2003 & Late Miocene & Anatolia \\
\hline & a Debruijnia arpati Ünay, 1996 & Early Miocene & Anatolia \\
\hline \multicolumn{4}{|c|}{$\begin{array}{l}\text { Vetusspalax De Bruijn, } \\
\text { Marković and Wessels, } 2013\end{array}$} \\
\hline & $\begin{array}{l}\text { a Vetusspalax progressus De Bruijn, } \\
\text { Marković and Wessels, } 2013\end{array}$ & Late Oligocene & Bosnia and Herzegovina \\
\hline \multicolumn{4}{|c|}{ Rhizomyinae Winge, 1887} \\
\hline \multicolumn{4}{|l|}{ Rhizomys Gray, 1831} \\
\hline & ${ }^{\mathrm{a}}$ Rhizomys sinensis Gray, 1831 & extant & China \\
\hline & 3 extant species & extant & China \\
\hline \multicolumn{4}{|c|}{ Tachyoryctes Rüppell, 1835} \\
\hline & ${ }^{\mathrm{a}}$ Tachyoryctes splendens Rüppell, 1835 & extant & Northeast Africa \\
\hline & 13 extant species & extant & Northeast Africa \\
\hline & Tachyoryctes pliocenicus Sabatier, 1978 & Pliocene & Ethiopia \\
\hline & Tachyoryctes konjiti Sabatier, 1982 & Pleistocene & Ethiopia \\
\hline & $\begin{array}{l}\text { Tachyoryctes makooka Wesselman, Black and } \\
\text { Asnake, } 2009\end{array}$ & Late Miocene & Ethiopia \\
\hline \multicolumn{4}{|c|}{ Cannomys Thomas, 1915} \\
\hline & ${ }^{\mathrm{a} C a n n o m y s ~ b a d i u s ~(H o d g s o n, ~ 1841) ~}$ & extant & SE Asia \\
\hline \multicolumn{4}{|c|}{ Protachyoryctes Hinton, 1933} \\
\hline & a Protachyoryctes tatroti Hinton, 1933 & Late Miocene & India \\
\hline \multicolumn{4}{|l|}{ Kanisamys Wood, 1937} \\
\hline & a'Kanisamys indicus Wood, 1937 & Middle and Late Miocene & Pakistan, India \\
\hline & Kanisamys sivalensis Wood, 1937 & Middle and Late Miocene & India, Pakistan \\
\hline & Kanisamys nagrii Prasad, 1968 & Late Miocene & India, Pakistan \\
\hline & Kanisamys potwarensis Flynn, 1982 & Middle and Late Miocene & India, Pakistan \\
\hline
\end{tabular}


Table 1 (continued)

\begin{tabular}{|c|c|c|c|}
\hline Subfamily and genus & Species & Occurences & Distribution \\
\hline \multicolumn{4}{|l|}{ Brachyrhizomys } \\
\hline \multicolumn{4}{|c|}{ Teilhard de Chardin, 1942} \\
\hline & $\begin{array}{l}\text { aBrachyrhizomys shansius (Teilhard de } \\
\text { Chardin, 1942) }\end{array}$ & Late Miocene / Early Pliocene & China \\
\hline & Brachyrhizomys shajius Flynn, 1993 & Late Miocene / Early Pliocene & China \\
\hline & Brachyrhizomys hehoensis Zheng, 1980 & Late Miocene / Early Pliocene & Tibet \\
\hline & Brachyrhizomys naquensis Zheng, 1980 & Late Miocene / Early Pliocene & Tibet \\
\hline \multicolumn{4}{|c|}{ Rhizomyides Bohlin, 1946} \\
\hline & ${ }^{\mathrm{a}}$ Rhizomyides punjabiensis (Colbert, 1933) & Late Miocene & India, Pakistan \\
\hline & Rhizomyides sivalensis (Lydekker, 1884) & Late Miocene & India, Pakistan \\
\hline & Rhizomyides mirzadi Lang and Lavocat, 1968 & Late Miocene & Afghanistan \\
\hline & $\begin{array}{l}\text { Rhizomyides saketiensis Gupta, Verma and } \\
\text { Tewari, } 1978\end{array}$ & Late Miocene & India \\
\hline & Rhizomyides carbonelli Brandy, 1979 & Late Miocene & Afghanistan \\
\hline & $\begin{array}{l}\text { Rhizomyides platytomeus Flynn, Heintz, Sen and } \\
\text { Brunet, } 1983\end{array}$ & Late Miocene & Afghanistan \\
\hline & Rhizomyides pinjoricus (Hinton, 1933) & Late Pliocene & India \\
\hline \multicolumn{4}{|c|}{$\begin{array}{l}\text { Prokanisamys De Bruijn, } \\
\text { Hussain and Leinders, } 1981\end{array}$} \\
\hline & $\begin{array}{l}\text { aprokanisamys arifi De Bruijn, Hussain and } \\
\text { Leinders, } 1981\end{array}$ & Early and Middle Miocene & India, Pakistan \\
\hline & $\begin{array}{l}\text { Prokanisamys benjavuni (Mein and Ginsburg, } \\
\text { 1985) }\end{array}$ & Early and Middle Miocene & Thailand, Pakistan \\
\hline & Prokanisamys kowalskii (Lindsay, 1996) & Early Miocene & Pakistan \\
\hline & $\begin{array}{l}\text { Prokanisamys major Wessels and De Bruijn, } \\
2001\end{array}$ & Early and Middle Miocene & Pakistan \\
\hline \multicolumn{4}{|c|}{ Anepsirhizomys Flynn, 1982} \\
\hline & aAnepsirhizomys opdykei Flynn 1982 & Pliocene & Pakistan \\
\hline \multicolumn{4}{|l|}{ Eicooryctes Flynn, 1982} \\
\hline & aEicooryctes kaulialensis Flynn, 1982 & Late Miocene & Pakistan \\
\hline \multicolumn{4}{|l|}{ Nakalimys } \\
\hline & ${ }^{a}$ Nakalimys lavocati Flynn and Sabatier, 1984 & Late Miocene & Kenya \\
\hline \multicolumn{4}{|l|}{ Pronakalimys } \\
\hline \multicolumn{4}{|c|}{ Tong and Jaeger, 1992} \\
\hline & a Pronakalimys andrewsi Tong and Jaeger, 1992 & Middle Miocene & Kenya \\
\hline \multicolumn{4}{|c|}{ Miorhizomys Flynn, 2009} \\
\hline & ${ }^{\mathrm{a}}$ Miorhizomys nagrii (Hinton, 1933) & Late Miocene / Early Pliocene & China, India, Pakistan \\
\hline & Miorhizomys pilgrimi (Hinton, 1933) & Late Miocene / Early Pliocene & China, India, Pakistan \\
\hline & Miorhizomys blacki (Flynn, 1982) & Late Miocene / Early Pliocene & China \\
\hline & Miorhizomys choristos (Flynn, 1982) & Late Miocene & India, Pakistan \\
\hline & Miorhizomys micrus (Flynn, 1982) & Late Miocene & India \\
\hline & Miorhizomys tetracharax (Flynn, 1982) & Late Miocene & China, India, Pakistan \\
\hline & Miorhizomys harii (Prasad, 1968) & Late Miocene / Early Pliocene & India \\
\hline
\end{tabular}

${ }^{\mathrm{a}}$ Type species

Wessels and De Bruijn (2001) to Prokanisamys because its cheek teeth lack the, for Eumyarion characteristic, strong anterior arm of the protocone in the M1 as well as the posterior arm of the hypoconid in the $\mathrm{ml}$ (Figs. 4 and 6). Since this transfer has been ignored by some authors (e.g. Flynn et al. 2013) we explicitly state that we adhere to our earlier generic allocation. For the sake of comparison, the tooth rows are depicted as if they are of the same size (Figs. 3, 4, 5 and 6).

\section{Concise review of the molecular genetic studies}

A number of molecular phylogenetic studies have been performed with the aim, among (many) other aims, of testing the hypothesis that the Rhizomyinae and the Spalacinae belong to the same early branch of the Muroidea. These studies are listed in Table 2. The results in general strongly indicate that the Rhizomyinae and the Spalacinae, together with the 
Fig. 3 Upper molars (M1, M2,

M3), occlusal and lingual view. a Heramys eviensis, Aliveri, Greece (Klein Hofmeijer and De Bruijn 1985), b Debruijnia arpati,

Keseköy, Anatolia (Ünay 1996), c Vetusspalax progressus,

Banovići, Bosnia and

Herzegovina (De Bruijn et al.

2013). The specimens are not to scale
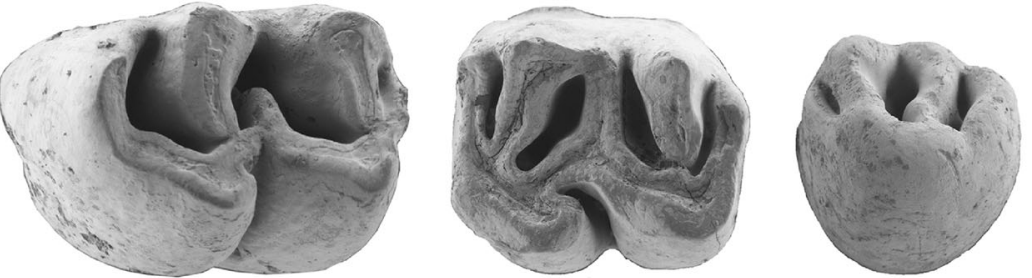

a
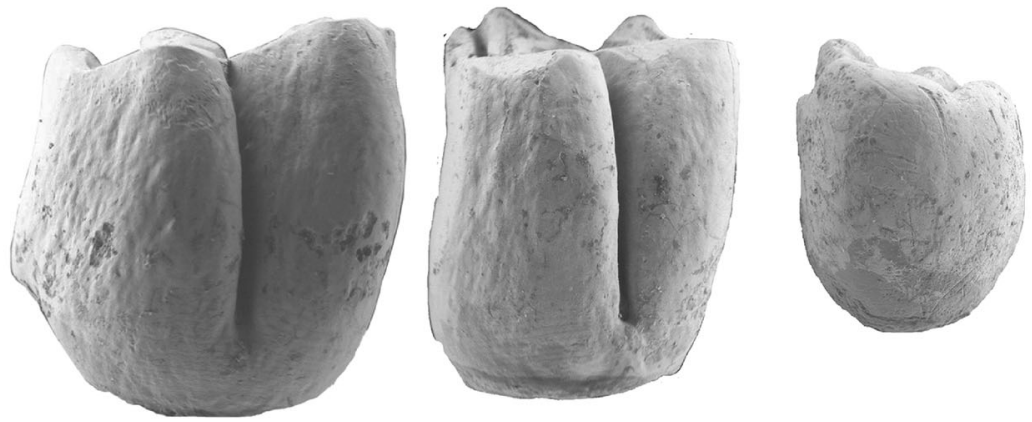

b
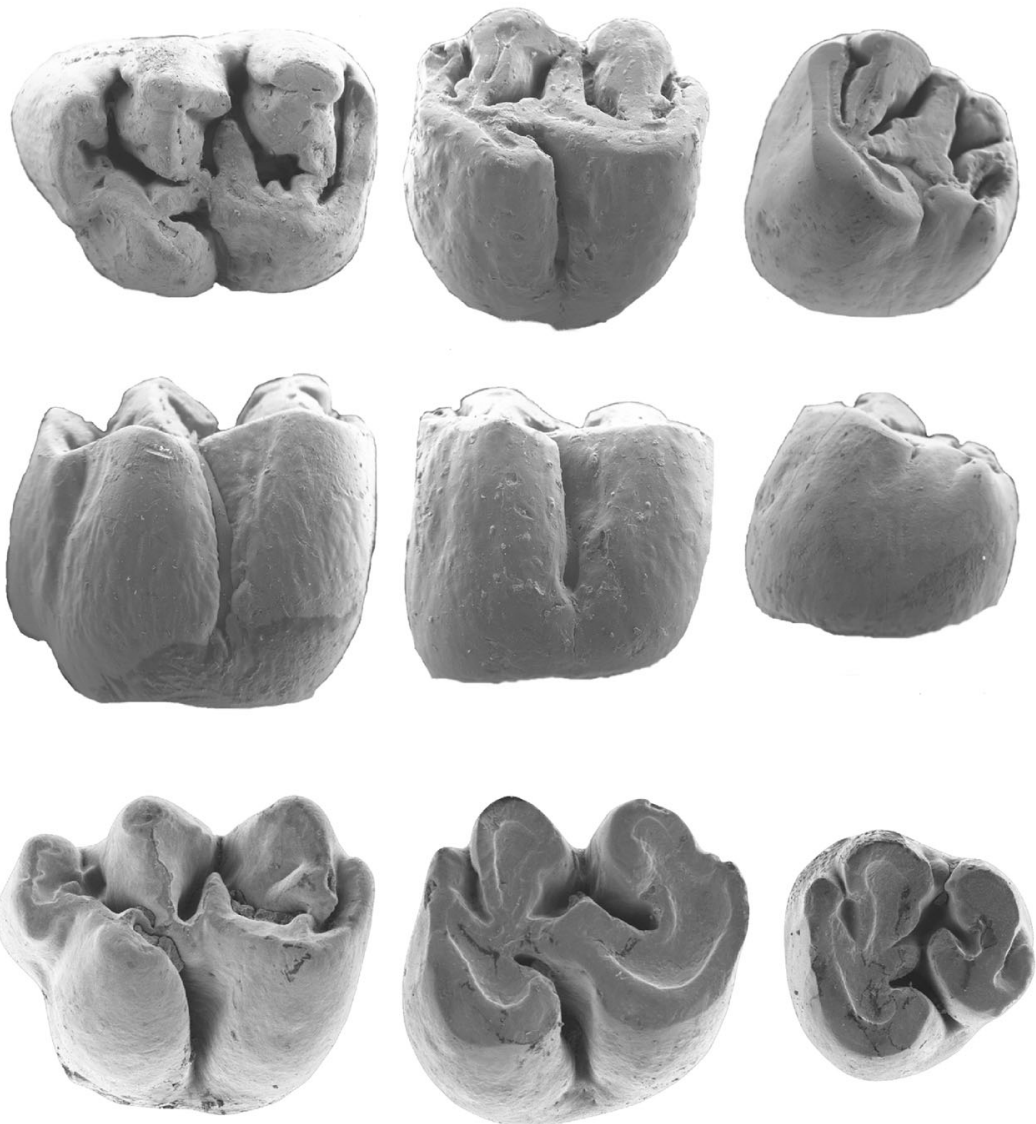

C
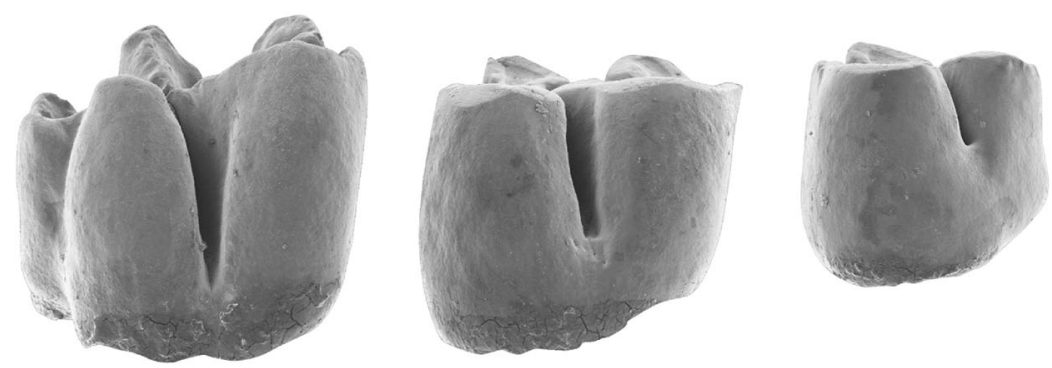

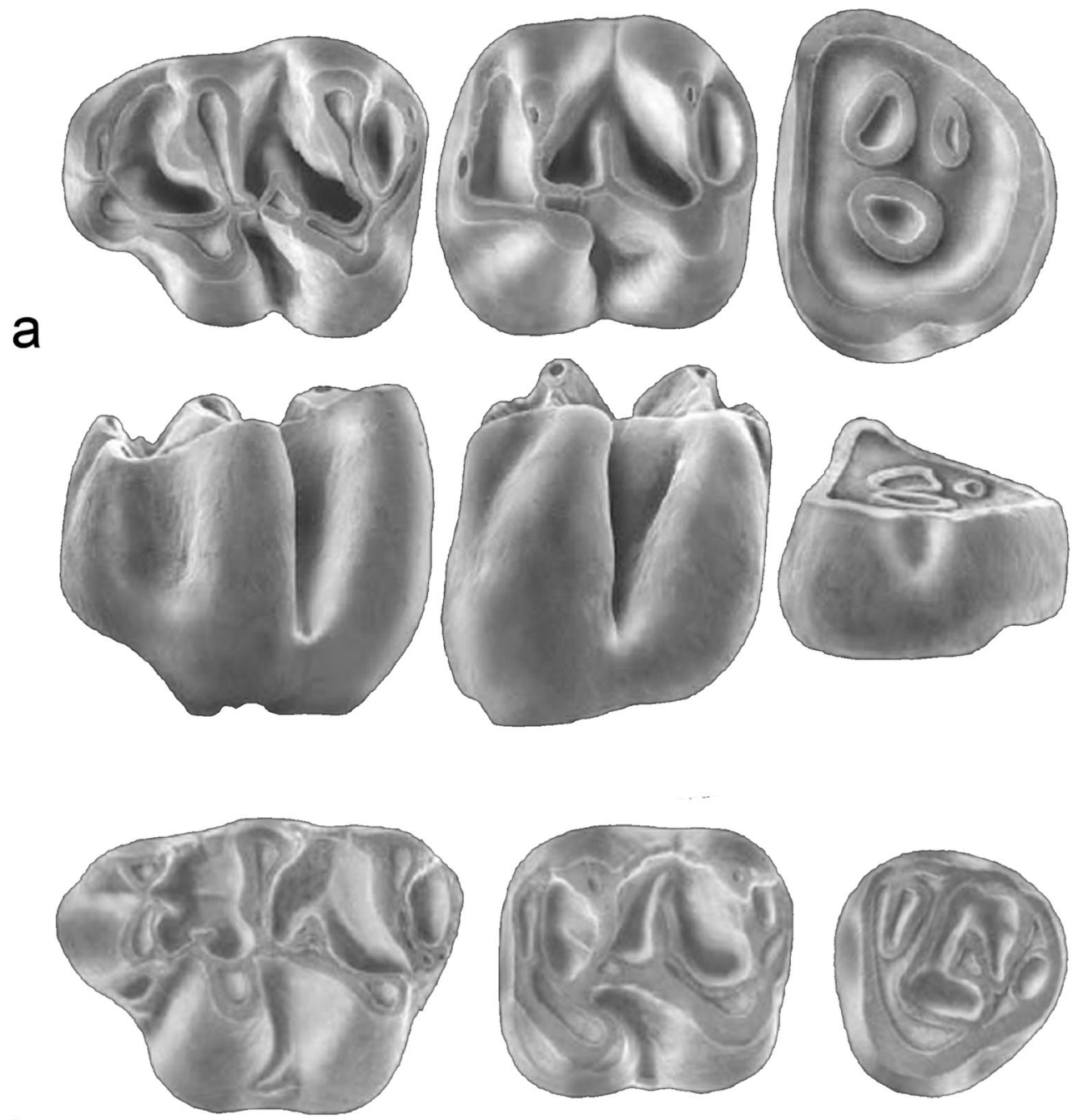

b
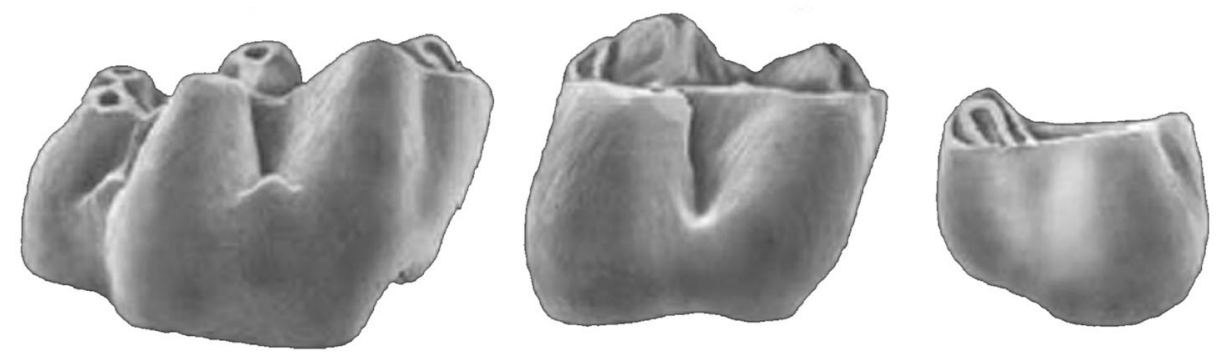

Fig. 4 Upper molars (M1, M2, M3), occlusal and lingual view. a Kanisamys indicus, Gaj River, Pakistan (Wessels and De Bruijn 2001), b Prokanisamys arifi, Gaj River, Pakistan (Wessels and De Bruijn 2001). The specimens are not to scale

Myospalacinae, form a separate clade within the Muroidea (Jansa and Weksler 2004; Norris et al. 2004; Blanga-Kanfi et al. 2009; Jansa et al. 2009; Gogolevskaya et al. 2010). Michaux et al. (2001), Norris et al. (2004) and Steppan et al. (2004), on the basis of their data, proposed placing the Rhizomyinae and the Spalacinae in a separate family, Spalacidae, leaving the family name Muridae to all other members of the superfamily Muroidea. The close relationship between the Myospalacinae and Rhizomyinae and the Spalacinae has been confirmed in a study by Lin et al. (2014) based on the results of transcriptome sequencing. Cytogenetic studies comparing chromosomes of species of the Rhizomyinae and the Spalacinae (e.g. by comparative painting) have not been performed.

\section{Concise review of the fossil data}

Most of the early fossil representatives of the Rhizomyinae and Spalacinae are known by dental remains only, so their life-style 
Fig. 5 Lower molars (m1, m2, $\mathrm{m} 3$ ), occlusal and labial view. a Heramys eviensis, Aliveri, Greece (Klein Hofmeijer and De Bruijn 1985), b Debruijnia arpati,

Keseköy, Anatolia (Ünay 1996), c Vetusspalax progressus,

Banovići, Bosnia and

Herzegovina (De Bruijn et al.

2013). The specimens are not to scale a
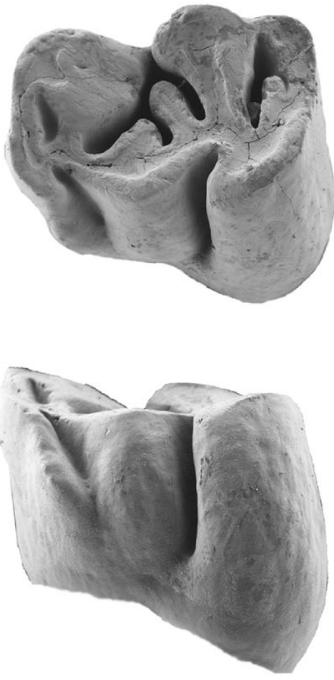

b
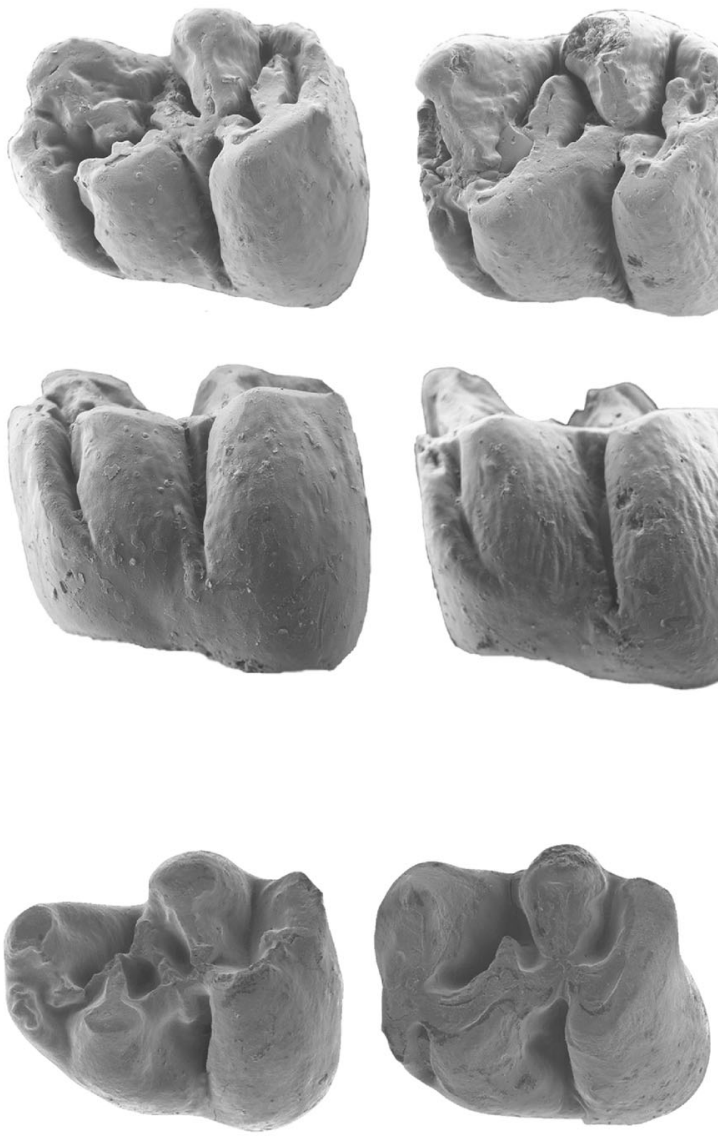

C

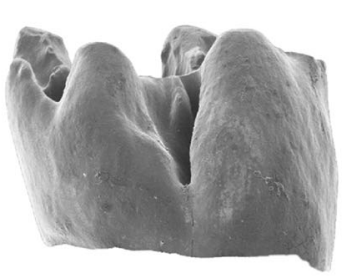

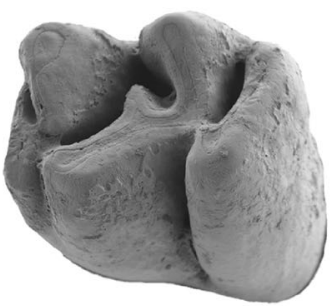
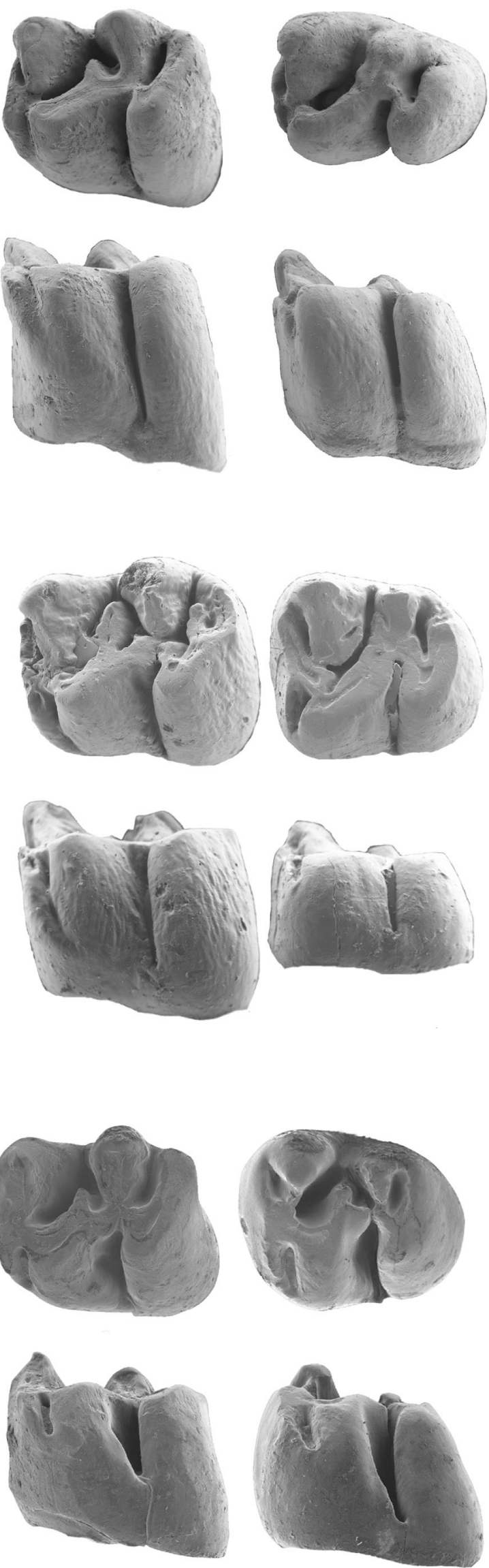

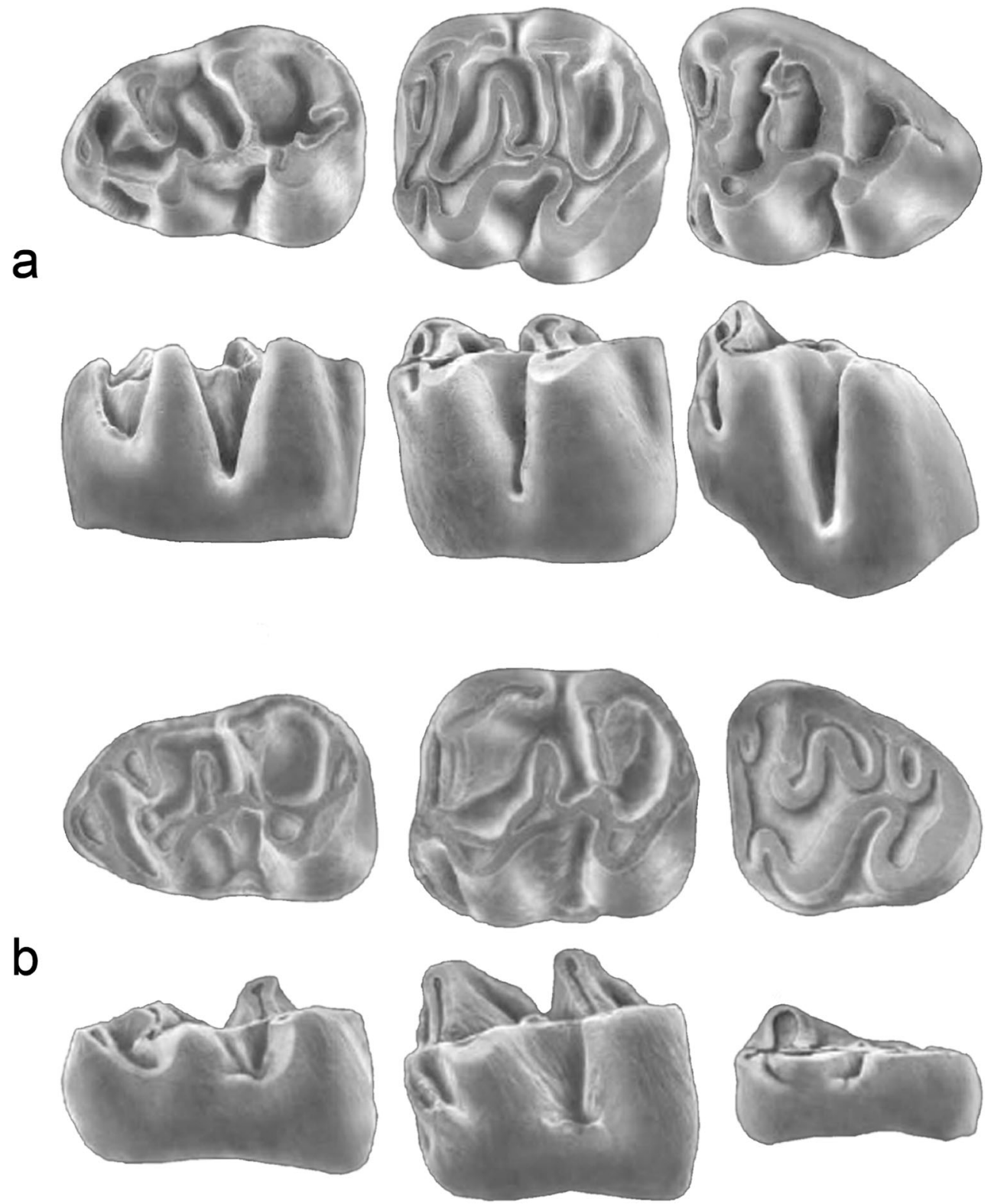

Fig. 6 Lower molars (m1, m2, m3, occlusal and labial view. a Kanisamys indicus Gaj River, Pakistan (Wessels and De Bruijn 2001), b Prokanisamys arifi Gaj River, Pakistan (Wessels and De Bruijn 2001). The specimens are not to scale

has to be inferred from the teeth, which introduces uncertainty. The development of dental similarity in these subfamilies as an adaptation to a fossorial life-style makes it difficult to distinguish grades from clades: the occurrence of the same morphologies in taxa does not necessarily mean that they are closely related as these morphologies can be derived independently (Wood 1965).

The Spalacinae Gray, 1821

The origin, taxonomy and phylogeny of the Spalacinae have been discussed by many authors (e.g. Petter 1961; De Bruijn et al. 1970; Fejfar 1972; De Bruijn 1984; Klein Hofmeijer and De Bruijn 1985; De Bruijn and Saraç 1991; Hugueney and Mein 1993; Ünay 1996; Sen and Sarica 2011). The genera
Rhizospalax (now in the Castoridae) and Prospalax (now in the Anomalomyinae) have in the past been considered to be Spalacinae. Fejfar (1972) suggested that the origin of the Anomalomyinae and Spalacinae was in the Tachyoryctoidinae, while others defended the view that the Anomalomyinae, the Tachyoryctoidinae and the Spalacinae are not closely related (Klein Hofmeijer and De Bruijn 1985; De Bruijn and Saraç 1991).

The first fossil true spalacine was recognised by Kormos in 1932-Pliospalax macovei from the Pliocene of Romania. A number of Pliospalax species of middle Miocene to late Pliocene age (Europe, Turkey and Ukraine) have been described since, with the first record of the subfamily pushed back in time by such new finds as Heramys eviensis (early 
Table 2 Molecular genetic studies analyzing phylogenetic relationships among Muroidea including Rhizomyinae and Spalacinae

\begin{tabular}{|c|c|c|}
\hline Genetic marker(s) ${ }^{\mathrm{a}}$ & Species considered $^{\mathrm{b}}$ & Reference \\
\hline \multirow[t]{3}{*}{ LCAT } & Rhizomys pruinosus $(\mathrm{R})$ & \\
\hline & Nannospalax ehrenbergi (S) & \\
\hline & Nannospalax leucodon (S) & Robinson et al. (1997) \\
\hline \multirow[t]{3}{*}{ LCAT } & Rhizomys pruinosus $(\mathrm{R})$ & \\
\hline & Nannospalax ehrenbergi (S) & \\
\hline & Nannospalax leucodon (S) & Michaux and Catzeflis (2000) \\
\hline \multirow[t]{2}{*}{ IRBP } & Rhizomys pruinosus $(\mathrm{R})$ & \\
\hline & Spalax zemni (S) & DeBry and Sagel (2001) \\
\hline \multirow[t]{3}{*}{ LCAT; vWF } & Rhizomys pruinosus $(\mathrm{R})$ & \\
\hline & Tachyoryctes sp. (R) & \\
\hline & Nannospalax ehrenbergi (S) & Michaux et al. (2001) \\
\hline \multirow[t]{3}{*}{ IRBP } & Rhizomys pruinosus $(\mathrm{R})$ & \\
\hline & Tachyoryctes splendens $(\mathrm{R})$ & \\
\hline & Spalax zemni (S) & Jansa and Weksler (2004) \\
\hline \multirow[t]{3}{*}{ 12S rRNA; cytochrome b } & Rhizomys pruinosus $(\mathrm{R})$ & \\
\hline & Rhizomys sinensis $(\mathrm{R})$ & \\
\hline & Nannospalax ehrenbergi (S) & Norris et al. (2004) \\
\hline GHR; BRCA1; RAG1 & Rhizomys pruinosus $(\mathrm{R})$ & \\
\hline \multirow[t]{2}{*}{ c-myc } & Tachyoryctes splendens (R) & \\
\hline & Spalax ehrenbergi (S) & Steppan et al. (2004) \\
\hline ADRA2B; CB1; GHR & Rhizomys pruinosus $(\mathrm{R})$ & \\
\hline \multirow[t]{3}{*}{ IRBP; RAG2; vWF } & Tachyoryctes sp. (R) & \\
\hline & Spalax ehrenbergi (S) & \\
\hline & Spalax zemni $(\mathrm{S})$ & Blanga-Kanfi et al. (2009) \\
\hline \multirow[t]{4}{*}{ IRBP; GHR } & Rhizomys pruinosus $(\mathrm{R})$ & \\
\hline & Tachyoryctes splendens $(\mathrm{R})$ & \\
\hline & Spalax zemni (S) & \\
\hline & Spalax ehrenbergi (S) & Jansa et al. (2009) \\
\hline \multirow[t]{2}{*}{ B1 SINE; 4.5S $\mathrm{S}_{1}$ RNA } & Tachyoryctes splendens $(\mathrm{R})$ & \\
\hline & Spalax microphthalmus (S) & Gogolevskaya et al. (2010) \\
\hline
\end{tabular}

(R), Rhizomyinae; (S), Spalacinae

${ }^{a}$ Nuclear genes: ADRA2B, BRCA1, CB1, c-myc, GHR, IRBP, LCAT, RAG1/2 and vWF. Mitochondrial genes: $12 \mathrm{~S}$ rRNA and cytochrome b. Other markers: $4.5 \mathrm{~S}_{1}$ RNA and B1 SINE. ADRA2B, Alpha $2 \mathrm{~B}$ adrenergic receptor; BRCA1, breast cancer gene 1; CB1, cannabinoid receptor 1; GHR, growth hormone receptor; IRBP, interphotoreceptor retinoid binding protein; LCAT, lecithin cholesterol acyl transferase; RAG1, recombination activating gene 1; RAG2, recombination activating gene 2; rRNA, ribosomal RNA; SINE, short interspersed element; vWF, von Willebrand factor

${ }^{\mathrm{b}}$ In all studies one individual per species was examined. These individuals are (probably) the same in Robinson et al. (1997), Michaux and Catzeflis (2000) and Michaux et al. (2001), and the same in Jansa and Weksler (2004), Steppan et al. (2004) and Jansa et al. (2009)
Miocene, MN4, Greece; Klein Hofmeijer and De Bruijn 1985), Debruijnia arpati (early Miocene, MN3, Anatolia; Ünay 1996) and Vetusspalax progressus (late Oligocene, MP30, Bosnia and Herzegovina; De Bruijn et al. 2013). The dentitions of these species share unmistakably spalacine characteristics, namely, (1) anterior wall of the protocone of the M1 being almost at right angles to the base of the crown; (2) fusion of the anterocone of the M1 into the anteroloph; (3) forward position of the metaconid of the $\mathrm{m} 1$ at the expense of the anteroconid. Heramys, Debruijnia and Vetusspalax do not represent one evolutionary lineage because the older Vetusspalax shows more derived characteristics than the younger Debruijnia (Figs. 3, 4, and 5). This points to an early radiation of the Spalacinae in southeastern Europe and the eastern Mediterranean area during the Oligocene. The fossil and extant geographical ranges of the Spalacinae roughly overlap (Figs. 1, 2), suggesting that the earliest spalacines recognised were already fossorial rodents because these are 
known to be limited in their dispersal abilities (Flynn 1982, 1990; Savič and Nevo 1990; Kryštufek and Griffiths 2002). The fossil record thus provides strong evidence that the Spalacinae developed a fossorial life-style much earlier than, and independently from, the Rhizomyinae.

\section{The Rhizomyinae Winge, 1887}

Hypothetically the earliest rhizomyine is supposed to have been a non-fossorial cricetine from the late Oligocene of southeast Asia (Wessels et al. 2003, 2008). Prokanisamys kowalskii from the earliest Miocene of Pakistan is the oldest record of the Rhizomyinae recognised. Prokanisamys has a wide geographical range in southeast Asia and reached North Africa during the early Miocene (Fig. 1; Wessels et al. 2003; Wessels 2009). Although the postcranial skeleton of Prokanisamys is not known, it is assumed that the species of that genus were not fossorial (Flynn 1982, 1985), an assumption supported by its wide geographical range. The adaptation to a fossorial life-style in the rhizomyines of southeast Asia seems to have taken place during the early late Miocene, and in the tachyoryctines of northeast Africa during the late Miocene and the Pliocene (Flynn 1982, 1990; Flynn and Sabatier 1984; Tong and Jaeger 1992; Wesselman et al. 2009). The rather poor fossil record of the African rhizomyines - there is no record of the group between the early Miocene Prokanisamys sp. from Libya and the late middle Miocene Pronakalimys from Kenya - does not confirm hypothesised explanations for the multiple migrations of Rhizomyinae from Asia to Africa as interpreted in LópezAntoňanzas et al. (2012). From a biological point of view, a long-distance migration of fossorial, territorial rodents is unlikely (Kryštufek and Griffiths 2002), so our working hypothesis is that the non-fossorial Prokanisamys migrated from Asia to Africa where it developed a fully fossorial mode of life independent of its Asian counterparts.

\section{The lower incisors of the Spalacinae and Rhizomyinae}

The lower incisors of many species of Spalacinae and Rhizomyinae show two longitudinal ribs in combination with the derived type ten or eleven microstructure of the enamel (Kalthoff 2000). This need not necessarily mean that these two groups are closely related, because the same traits of the lower incisors occur in a number of other subfamilies of the Muridae, such as in the late Oligocene and Miocene Eumyarioninae and Cricetodontinae. Apparently, this combination of characteristics of lower incisors developed a number of times in different subfamilies.

\section{The evolutionary dynamics of the Rhizomyinae and Spalacinae}

Table 3 summarises the numbers of genera and species of the Rhizomyinae and the Spalacinae in the four time slices defined in Figs. 1 and 2. The Spalacinae show a generic decline during the middle Miocene which is almost certainly an artefact due to the paucity of studies on the collections from the middle Miocene of Anatolia. Their representation in terms of numbers of genera and species (Table 3) during the late Miocene/early Pliocene probably reflects reality. The Rhizomyinae play a modest role until the late Miocene, when they became very diverse, in particular in the northern part of the Indian subcontinent. This radiation may well correlate with the development of a fossorial life-style, which may have enhanced a mosaic type of evolution.

\section{Conclusions}

The discrepancy between the opinions of geneticists and palaeontologists on the relationship of the Rhizomyinae and Spalacinae is intriguing and not understood. Explanations may perhaps be sought in the restrictions inevitably connected with the methods used in the genetic studies of Table 2 and in the incompleteness inherent to the fossil record. New insights may be obtained through the application of advanced molecular genetic techniques (genome and transcriptome sequencing) such as those which have already been used for rhizomyine and spalacine species by Zhao et al. (2013), Fang et al. (2014) and Lin et al. (2014).

Although the fossil record of the Rhizomyinae and Spalacinae is relatively good, it is clear that much of the earliest history of these subfamilies is not documented. The oldest spalacine known, Vetusspalax from the late Oligocene of southeast Europe, has a much too derived dentition to be ancestral to all later ones. The radiation of the Spalacinae must thus have occurred earlier in the Oligocene. The oldest rhizomyine known, the non-fossorial Prokanisamys from the

Table 3 The number of genera and species of the Rhizomyinae and Spalacinae $^{\mathrm{a}}$

\begin{tabular}{llllll}
\hline \multirow{2}{*}{ Time slice } & \multicolumn{2}{l}{ Rhizomyinae } & & \multicolumn{2}{l}{ Spalacinae } \\
\cline { 2 - 3 } \cline { 6 - 6 } \cline { 5 - 6 } & Genera & Species & & Genera & Species \\
\hline Late Miocene/Pliocene & 9 & 26 & & 8 \\
Midde Miocene & 3 & 7 & & 4 \\
Early Miocene & 1 & 4 & & 4 \\
Late Oligocene & 0 & 0 & & 1 & 1 \\
\hline
\end{tabular}

${ }^{\mathrm{a}}$ Only published species, as mentioned in Table 1 
earliest Miocene of the Indian subcontinent, can not yet be traced to a specific muroid ancestor.

Until the differences in opinion between geneticists and palaeontologists are resolved, we propose to classify the Rhizomyinae and the Spalacinae as separate subfamilies within the Muridae.

Acknowledgements This paper is to honour Albert van der Meulen, friend and colleague. The paper benefitted from the constructive comments of the reviewers Dr. M. Hugueney and Dr. L.J. Flynn. Figures 1 and 2 were made by the late Tom van Hinte, and Tilly Bouten assisted with the Scanning Electron Microscopy.

Open Access This article is distributed under the terms of the Creative Commons Attribution 4.0 International License (http://creativecommons.org/licenses/by/4.0/), which permits unrestricted use, distribution, and reproduction in any medium, provided you give appropriate credit to the original author(s) and the source, provide a link to the Creative Commons license, and indicate if changes were made.

\section{References}

Blanga-Kanfi, S., Miranda, H., Penn, O., Pupko, T., DeBry, R. W., \& Huchon, D. (2009). Rodent phylogeny revised, analysis of six nuclear genes from all major rodent clades. BMC Evolutionary Biology. doi:10.1186/1471-2148-9-71.

Bohlin, B. (1946). The fossil mammals from the Tertiary deposit of Taben-buluk, Part II: simplicidentata, carnivora, artiodactyla, perissodactyla, and primates. Sino-Swedish Expedition Publication. Palaeontologica Sinica n.s. C 8B(28), 1-259.

Brandy, L. D. (1979). Rongeurs nouveaux du Néogène d' Afghanistan. Comptes Rendus de l'Academie des Sciences de Paris D, 289, 8183.

Bruijn, H. de (1984). Remains of the mole-rat Microspalax odessanus Topachevski, from Karaburun (Greece, Macedonia) and the family Spalacidae. Proceedings Koninklijke Nederlandse Akademie van Wetenschappen B, 87(4), 417-425.

Bruijn, H. de, \& Saraç, G. (1991). Early Miocene faunas from the eastern Mediterranean area. Part 1, The genus Eumyarion. Proceedings Koninklijke Nederlandse Akademie van Wetenschappen B, 94(1), $1-36$.

Bruijn, H. de, Dawson, M. R., \& Mein, P. (1970). Upper Pliocene Rodentia, Lagomorpha and Insectivora (Mammalia) from the Isle of Rhodes (Greece). Proceedings Koninklijke Nederlandse Akademie van Wetenschappen B, 73(5), 535-584.

Bruijn, H. de, \& Meulen, A. J. van der (1975). The early Pleistocene rodents from Tourkobounia-1 (Athens, Greece). Proceedings Koninklijke Nederlandse Akademie van Wetenschappen B, 78(4), 314-338.

Bruijn, H. de, Hussain, S. T., \& Leinders, J. M. (1981). Fossil rodents from the Murree Formation near Banda Daud Shah, Kohat, Pakistan. Proceedings Koninklijke Nederlandse Akademie van Wetenschappen B, 84(1), 71-99.

Bruijn, H. de, Marković, Z., \& Wessels, W. (2013). Late Oligocene rodents from Banovići (Bosnia and Herzegovina). Palaeodiversity, 6, 63-105.

Colbert, E. H. (1933). Two new rodents from the lower Siwalik beds of India. American Museum Novitates, 633, 1-6.

DeBry, R. W., \& Sagel, R. M. (2001). Phylogeny of Rodentia (Mammalia) inferred from the nuclear-encoded gene IRBP. Molecular Phylogenetics and Evolution, 19(2), 290-301.
Fang, X., Nevo, E., Han, L., Levanon, E. Y., Zhao, J., Avivi, A., et al. (2014). Genome-wide adaptive complexes to underground stresses in blind mole rats Spalax. Nature Communications, 5, 3966. doi:10. 1038/ncomms4966.

Fejfar, O. (1972). Ein neuer Vertreter der Gattung Anomalomys Gaillard, 1900 (Rodentia, Mammalia) aus dem europäischen Miozän (Karpat). Neues Jahrbuch für Paläontologie, Abhandlungen, 141(2), 168-193.

Flynn, L. J. (1982). A revision of fossil rhizomyid rodents from northern India and their correlation to a rhizomyid biochronology of Pakistan. Geobios, 15(4), 583-588.

Flynn, L. J. (1985). Evolutionary patterns and rates in Siwalik Rhizomyidae (Rodentia). Acta Zoologica Fennica, 170, 141-144.

Flynn, L. J. (1990). The natural history of rhizomyid rodents. In E. Nevo \& O. Reig (Eds.), Evolution of subterranean mammals at the organismal and molecular levels (pp. 155-183). New York: A.R. Liss.

Flynn, L. J. (1993). A new bamboo rat from the Late Miocene of the Yushe Basin. Vertebrata PalAsiatica, 311, 95-101.

Flynn, L. J. (2009). The antiquity of Rhizomys and independent acquisition of Fossorial traits in subterranean Muroids. Bulletin of the American Museum of Natural History, 331, 128-156.

Flynn, L. J., \& Qi, G. (1982). The age of the Lufeng, China, hominoid locality. Nature, 298(5876), 746-747.

Flynn, L. J., \& Sabatier, M. (1984). A muroid rodent of Asian affinity from the Miocene of Kenia. Journal of Vertebrate Paleontology, 3(3), 160-165.

Flynn, L. J., Heintz, E., Sen, S., \& Brunet, M. (1983). A new Pliocene tachyoryctine (Rhizomyidae, Rodentia) from Lataband, Sarobi Basin, Afghanistan. Proceedings Koninklijke Nederlandse Akademie van Wetenschappen B, 86, 61-68.

Flynn, L. J., Jacobs, L. L., \& Lindsay, E. H. (1984). Problems of muroid phylogeny, relationship to other rodents and origin of major groups. In W. P. Luckett \& J. L. Hartenberger (Eds.), Evolutionary relationships among rodents, a multidisciplinary analysis (Nato ASI series A, pp. 589-616). New York: Plenum Press.

Flynn, L. J., Lindsay, E. H., Pilbeam, D., Raza, M. S., Morgan, M. E., Barry, J. C., Badgley, C. E., Behrensmeyer, A. K., Cheema, I. U., Rajpar, R. A., \& Opdyke, N. D. (2013). The Siwaliks and Neogene evolutionary biology in South Asia. In X. Wang, L. J. Flynn, \& M. Fortelius (Eds.), Fossil mammals of Asia (Neogene Biostratigraphy and Chronology, pp. 353-372). New York: Columbia University Press.

Gogolevskaya, I. K., Veniaminova, N. A., \& Kramerov, D. A. (2010). Nucleotide sequences of B1 SINE and 4.5S(I) RNA support a close relationship of zokors to blind mole rats (Spalacinae) and bamboo rats (Rhizomyinae). Gene, 460(1-2), 30-38. doi:10.1016/j.gene. 2010.04.002.

Gray, J. E. (1821). On the natural arrangement of vertebrose animals. London Medical Repository, 15, 296-310.

Gray, J. E. (1831). Characters of three new genera (Helictis, Paguma and Rhizomys), including two new species of Mammalia from China. Proceedings of the Committee of Science and Correspondence of the Zoological Society of London, part 1, 94-96.

Güldenstaedt, A. I. (1770). Peregusna nova mustelae species. Novi Commentari Academiae Scientiarum Imperialis Petropolitanae, 14, 441-455.

Gupta, S. S., Verma, B. C., \& Tewari, A. P. (1978). New fossil hominoid material from the Siwaliks of Kangra District, Himachal Pradesh. Journal of the Paleontological Society of India, 27, 111-115.

Hinton, M. A. C. (1933). Diagnoses of new genera and species of rodents from the Indian Tertiary deposits. Annals and Magazine of Natural History, 10, 620-622.

Hodgson, B. H. (1841). New species of Rhizomys discovered in Nepal (R. badius, Bay Bamboo Rat). Calcutta Journal of Natural History, $2,60-61,410-411$. 
Hugueney, M., \& Mein, P. (1993). A comment on the earliest Spalacinae (Rodentia, Muroidea). Journal of Mammalian Evolution, 1(3), 215223

Jansa, S. A., \& Weksler, M. (2004). Phylogeny of muroid rodents, relationships within and among major lineages as determined by IRBP gene sequences. Molecular Phylogenetics and Evolution, 31(1), 256-276. doi:10.1016/j.ympev.2003.07.002.

Jansa, S. A., Giarla, T. C., \& Lim, B. K. (2009). The phylogenetic position of the rodent genus Typhlomys and the geographic origin of Muroidea. Journal of Mammalogy, 90(5), 1083-1094.

Kalthoff, D. C. (2000). Die Schmelzmicrostruktur in den Incisiven der hamsterartigen Nagetiere und anderer Myomorpha (Rodentia, Mammalia). Palaeontographica A, 269, 1-193.

Klein Hofmeijer, G., \& Bruijn, H. de (1985). The mammals from the lower Miocene of Aliveri (island of Evia, Greece). Proceedings Koninklijke Nederlandse Akademie van Wetenschappen B, 88(2), 185-198.

Kormos, T. (1932). Neue Pliozäne Nagetiere aus der Moldau. Paläontologische Zeitschrift, 14(3), 193-200.

Kryštufek, B., \& Griffiths, H. I. (2002). Species richness and rarity in European rodents. Ecography, 25, 120-128.

Lang, J., \& Lavocat, R. (1968). Prémiere découverte d'une faune de vertébrés dans le Tertiaire d'Afghanistan et datation de la série de Bamian. Comptes Rendus de l'Académie des Sciences de Paris D, 266, 79-82.

Lin, G. H., Wang, K., Deng, X. G., Nevo, E., Zhao, F., Su, J. P., Guo, S. C., Zhang, T. Z., \& Zhao, H. (2014). Transcriptome sequencing and phylogenomic resolution within Spalacidae (Rodentia). BMC Genomics 15, 32. doi:10.1186/1471-2164-15-32.

Lindsay, E. H. (1996). A new eumyarionine cricetid from Pakistan. Acta Zoologica Cracoviensia, 39(1), 279-288.

López-Antoňanzas, R., Flynn, L. J., \& Knoll, F. (2012). A comprehensive phylogeny of extinct and extant Rhizomyinae (Rodentia), evidence for multiple intercontinental dispersals. Cladistics, 29(3), 247-273. doi:10.1111/j.1096-0031.2012.00426.x.

Lydekker, R. L. (1884). Rodents and new ruminants from the Siwaliks and synopsis of Mammalia. Paleontographica Indica, 10, 134-185.

Marković, Z. (2003). The Miocene small mammals of Serbia, a review. In J. W. F. Reumer, \& W. Wessels (Eds.), Distribution and migration of Tertiary mammals in Eurasia. Deinsea, 10, 393-398.

McKenna, M. C., \& Bell, S. K. (1997). Classification of mammals above the species level. New York: Columbia University Press.

Mein, P., \& Ginsburg, L. (1985). Les rongeurs Miocènes de Li (Thailande). Comptes rendus hebdomadaires des Séances de l' Académie des Sciences 2, 301(19), 1369-1374.

Michaux, J., \& Catzeflis, F. (2000). The bushlike radiation of muroid rodents is exemplified by the molecular phylogeny of the LCAT nuclear gene. Molecular Phylogenetics and Evolution, 17(2), 280293.

Michaux, J., Reyes, A., \& Catzeflis, F. (2001). Evolutionary history of the most speciose mammals, molecular phylogeny of muroid rodents. Molecular Biology and Evolution, 18(11), 2017-2031.

Norris, R. W., Zhou, K., Zhou, C., Yang, G., Kilpatrick, W. C., \& Honeycutt, R. L. (2004). The phylogenetic position of the zokors (Myospalacinae) and comments on the families of muroids (Rodentia). Molecular Phylogenetics and Evolution, 31(3), 972978. doi:10.1016/j.ympev.2003.10.020.

Palmer, T. S. (1903). Some new generic names of mammals. Science New Series, 17,873 .

Petter, F. (1961). Affinités des genres Spalax et Brachyuromys (Rongeurs, Cricetidae). Mammalia, 25, 485-497.

Prasad, K. N. (1968). The vertebrate fauna from the Siwalik beds of Haritalyangar, Himachal Pradesh, India. Memoirs of the Geological Survey of India, Palaeontologia Indica, 39, 1-56.

Robinson, M., Catzeflis, F., Briolay, J., \& Mouchiroud, D. (1997). Molecular phylogeny of rodents, with special emphasis on murids, evidence from nuclear gene LCAT. Molecular Phylogenetics and Evolution, 8(3), 423-434. doi:10.1006/mpev.1997.0424.

Rüppell, E. (1835). Neue Wirbelthiere zu der Fauna von Abyssinien gehörig. Säugethiere, 1, 36.

Sabatier, M. (1978). Un nouveau Tachyoryctes (Mammalia, Rodentia) du bassin Pliocène de Hadar (Ethiopie). Geobios, 11, 95-99.

Sabatier, M. (1982). Les Rongeurs du site Pliocène à Homonidés de Hadar (Ethiopie). Paleovertebrata, 12(1), 1-56.

Sarıca, N., \& Sen, S. (2003). Spalacidae (Rodentia). In M. Fortelius, J. Kappelman, S. Sen, \& R. L. Bernor (Eds.), Geology and paleontology of the Miocene Sinap formation, Turkey (pp. 141-162). Columbia University Press: New York.

Savič, I. R., \& Nevo, E. (1990). The Spalacidae, evolutionary history, speciation and population biology. In E. Nevo \& O. A. Reig (Eds.), Evolution of subterranean mammals at the organismal and molecular levels (pp. 129-154). New York: Wiley-Liss.

Sen, S., \& Sarıca, N. (2011). Middle-Late Miocene Spalacidae (Mammalia) from western Anatolia, and the phylogeny of the family. Bulletin of the Earth Sciences Application Centre of the Hacetepe University, 32(1), 21-50.

Simionescu, I. (1930). Vertebratele Pliocene de la Malușteni (Covurlui). Publications du Fondation Vasile Adamachi, Akademia Romana, 9(49), 83-151.

Steppan, S. J., Adkin, R. M., \& Anderson, J. (2004). Phylogeny and divergence-date estimates of rapid radiations in muroid rodents based on multiple nuclear genes. Systematic Biology, 53(4), 533553. doi:10.1080/10635150490468701.

Teilhard de Chardin, P. (1942). New rodents of the Pliocene and lower Pleistocene of north China. Publications of the Institute of GeoBiology, 9, 1-101.

Theocharopoulos, K. D. (2000). Late Oligocene-middle Miocene Democricetodon, Spanocricetodon and Karydomys n. gen. from the eastern mediterranean area. Gaia, 8, 1-116.

Thomas, O. (1896). On the genera of rodents, An attempt to bring up to date the current arrangement of the order. Proceedings of the Zoological Society of London, 64, 1012-1028.

Thomas, O. (1915). Notes on the Asiatic bamboo-rats (Rhizomys etc.). Annals and Magazine of Natural History, 8(16), 56-61.

Tong, H., \& Jaeger, J. J. (1992). Muroid rodents from the Middle Miocene Fort Ternan locality (Kenya) and their contribution to the phylogeny of muroids. Palaeontographica Abteilung A, Paleozoologie-Stratigraphie, 229(1-3), 51-73.

Topachevski, V. A. (1969). Fauna of the USSR, mammals, mole rats, Spalacidae. In Academy of Sciences of the USSR, (Ed.), Fauna of the USSR, Mammals (Zoological Institute, new series, Vol. 99, pp. 1-150). New Delhi: Amerind Publishing Co Pvt. Ltd.

Ünay, E. (1978). Pliospalax primitivus and Anomalomys gaudryi Gaillard from the Anchitherium fauna of Sarıçay. Bulletin of the Geological Society of Turkey, 21, 121-128.

Ünay, E. (1990). A new species of Pliospalax (Rodentia, Mammalia) from the Middle Miocene of Paşalar, Turkey. Journal of Human Evolution, 19, 445-453.

Ünay, E. (1996). On fossil Spalacidae (Rodentia). In R. L. Bernor (Ed.), The evolution of western Eurasian Neogene Mammal Faunas (pp. 246-252). New York: Columbia University Press.

Ünay, E., Bruijn, H. de, \& Saraç, G. (2003). A preliminary zonation of the continental Neogene of Anatolia based on rodents. In J. W. F Reumer, \& W. Wessels (Eds.), Distribution and migration of Tertiary mammals in Eurasia. Deinsea 10, 539-548.

Vasileiadou, K., \& Koufos, G. D. (2005). The micromammals from the Early/Middle Miocene locality of Antonios, Chalkidiki, Greece. Annales de Paleontologie, 91, 197-225.

Wesselman, H. B., Black, M. T., \& Asnake, M. (2009). Small mammals. In Y. Haile-Selassi \& G. WoldeGabriel (Eds.), Ardipithecus kadabba, Late Miocene evidence from the Middle Awash, Ethiopia (pp. 105-134). Berkeley: University of California Press. 
Wessels, W. (2009). Miocene rodent evolution and migration. Muroidea from Pakistan, Turkey and Northern Africa. Geologica Ultraiectina, 307, 1-290.

Wessels, W., \& Bruijn, H. de (2001). Rhizomyidae from the lower Manchar formation Miocene, Pakistan. Annals of Carnegie Museum, 70(2), 143-168.

Wessels, W., Fejfar, O., Peláez-Campomanes, P., Meulen, A. J. van der, Bruijn, H. de, \& El-Arnauti, A. (2003). Miocene small mammals from Jebel Zelten, Libya. In N. López-Martínez, P. PeláezCampomanes \& M. Hernández Fernández (Eds.), Surrounding Fossil Mammals, Dating, Evolution and Paleoenvironment (pp. 699-715). Coloquios de Paleontología, Volumen Extraordinario n 1 en homenaje al Dr Remmert Daams.

Wessels, W., Fejfar, O., Peláez-Campomanes, P., Meulen, A. J. van der, Bruijn, H. de, \& El-Arnauti, A. (2008). The age of the small mammal faunas from Jabal Zaltan. Libia, Garyounis Scientific Bulletin, $5,129-138$.
Wilson, D. E., \& Reeder, D. M. (2005). Mammal species of the world. A taxonomic and geographic reference. Baltimore: Johns Hopkins University Press.

Winge, H. (1887). Jordfundne og nulevende Gnavere (Rodentia) fra Lagoa Santa, Minas Geraes, Brasilien. Museo Lundii, Copenhague, 1(3), 1-178.

Wood, A. E. (1937). Fossil rodents from the Siwalik Beds of India. American Journal of Sciences, 36, 64-76.

Wood, A. E. (1965). Grades and clades among rodents. Evolution, 19(1), $115-130$.

Zhao, F., Zhang, T., Su, J., Nevo, E., \& Lin, G. (2014). Mitochondrial genome of bamboo rat Rhizomys pruinosus. Mitochondrial DNA5(5):381-382. doi:10.3109/19401736.2013.809434

Zheng, S. H. (1980). The Hipparion fauna of Bulong Basin, Biru, Xizang. In Qinghai-Tibetan Plateau Comprehensive Scientific Investigation Team of Chinese Academy of Sciences (Ed.), Paleontology of Tibet, Part 1 (pp. 33-47). Beijing: Science Press. 